\title{
Computational, Pharmacological and Toxicological Approach of Repurposed Lamotrigine Schiff Base Derivatives for Reduction of Hormone-Positive Breast Tumor
}

Saima Najm ( $\nabla$ saminajm@hotmail.com )

Riphah International University

Humaira Naureen

Riphah International University

Fareeha Anwar

Riphah Institute of Pharmaceutical Sciences, Riphah International University

Muhammad Mubbashir Khan

Lahore College of Pharmaceutical Sciences

Rabia Ali

University of Central Punjab

\section{Research Article}

Keywords: Lamotrigine, NMU, cytotoxic, MCF-7, schiff base, breast cancer.

Posted Date: November 22nd, 2021

DOI: https://doi.org/10.21203/rs.3.rs-1026443/v1

License: (c) (1) This work is licensed under a Creative Commons Attribution 4.0 International License.

Read Full License 


\title{
Computational, Pharmacological and Toxicological Approach of Repurposed Lamotrigine Schiff Base Derivatives for Reduction of Hormone-Positive Breast Tumor
}

\author{
Saima Najm, 2*, Humaira Naureen", Fareeha Anwar³, Muhammad \\ Mubbashir Khan², Rabia Ali ${ }^{4}$
}

${ }^{1}$ Faculty of Pharmaceutical Sciences, Riphah International University, Islamabad 44000, Pakistan

${ }^{2}$ Faculty of Pharmacy, Lahore College of Pharmaceutical Sciences, Lahore 55150, Pakistan

${ }^{3}$ Riphah Institute of Pharmaceutical Sciences, Riphah International University, Lahore 55150, Pakistan

${ }^{4}$ Faculty of Pharmacy, University of Central Punjab, Lahore 55150, Pakistan

\section{Corresponding Author:}

\section{Saima Najm}

Email: saminajm@hotmail.com; orcid.org/0000-0002- 2588-7037. 


\section{Abstract:}

Background and objectives: Breast cancer presents high morbidity among women with various treatment challenges. This study aims to evaluate the repurposed lamotrigine schiff base metal (LTG-SB-M) coordinates against in-vitro MCF-7 breast cancer cell lines and invivo $\mathrm{N}$ - methylnitrosourea (NMU)-persuaded toxicity of rats' mammary gland.

Method: In-silico computational analysis and in vitro cytotoxic studies on MCF-7 breast cancer cell lines was executed to build up the assumptions. In-vivo NMU-induced anticancer potential was assessed in forty female Wistar rats; assigned into five groups of 8 rats each. Group I served as normal control and received normal saline, Group II received NMU (50 mg/kg), Group III received tamoxifen, whereas; Group IV and V received LTGSB-M derivative (LAC3, LBC3) at dose of $100 \mathrm{mg} / \mathrm{kg}$ body weight, for 15 consecutive days. Intraperitoneal injection of NMU (single dose) was given at the age of 5, 9 and 13 weeks to the rats with the three week interval. For all experimental animals; biochemical markers were assessed. DNA strand breakage alongside the hormonal profile of estrogen and progesterone was also estimated.

Results: All tested compounds present significant activity against MCF-7 cell lines in vitro and NMU-induced mammary tumor in vivo. The in vivo results of tested compounds present a significant decrease in weight of organ; with reinstated renal and hepatic enzymes. Histological analysis revealed strong countenance of proteins, estrogen, and progesterone in NMU-treated rats.

Conclusion: These results suggest that LTG-SB-M complex can be used as better anticancer agent against breast cancer.

Key word: Lamotrigine, NMU, cytotoxic, MCF-7, schiff base, breast cancer. 


\section{INTRODUCTION}

Cancer is one of the leading universal health vulnerabilities (Siegel et al., 2019); which comprehend varied inhabitants of unusual cell growth; hereditarily altered to incredulous cell propagation blockades and able to metastasis of remaining tissues of body (Harbeck et al., 2019). Amongst all tumor kinds; breast cancer (BC) is the utmost dominant neoplastic illness one of the major root of decease amongst womanhood internationally (Yankuzo et al., 2018). From clinical point of view, BC is sub classified into three types; which includes triple negative breast cancer (TNBC), human epithelial growth factor receptor two overexpression (HER2), and positive hormone receptor $(\mathrm{HR}+)$ (whether progesterone receptor $(\mathrm{PR}+)$ positive or estrogen receptor $(\mathrm{ER}+)$ positive) tumors (Nagini, 2017). Similarly, oxidative stress contributes in pathology of tumor by varying the hereditary constancy and triggering DNA breakdown, carcinogenesis, cell propagation, and oncogene mutations; complicating the state of disease (Hecht et al., 2016).

In this perspective, numerous antiepileptic drugs (AEDs) were thought to be linked with anti-cancer action in various malignancies, comprising breast, both in-vitro and in-vivo (Kawagoe et al., 2002; Olsen et al., 2004; Nelson et al., 2015). Lamotrigine (LTG) acts as a synthetic phenyltriazine with anticonvulsant properties, commercially available since mid-90 for the treatment of epilepsy and bipolar disorder (Najib and Mustafa, 2014). The anticonvulsant consequence of LTG revealed from binding along voltage gated sodium channel (VNaC), therefore preventing the release of acetylcholine (Valle et al., 2007; Kim et al., 2017). LTG-SB protects against seizures by numerous cellular targets, similar to ion channels, neurotransmitter transporter, synaptic vesicle protein and neurotransmitter metabolic enzyme (Robert, 2010). They coordinate to an extensive range of metal ions and form metal complexes with various oxidation states and protect against cancer as well (Saima et al., 2021). The biological effects and molecular mechanism of LTG were investigated in both ER+ (including tamoxifen resistant cells models) and ER- BC cells in 
vitro, while its inspiration on breast tumor growth was tested in vivo, using a xenograft model (Pellegrino et al., 2018).

The simplest method used from several decades for producing a nearly complete substitute model of human mammary carcinomas is the initiation of female rats' mammary tumors of susceptible strains by NMU; that closely mimics the human disease in terms of tumor histology and hormone dependence (Gullino et al., 1975). It is a direct acting carcinogen with a very short half-life; and does not require the metabolic activation steps for formation of DNA adducts like other carcinogens (Tessa et al., 2009). Computational analysis of metal grounded schiff base ligand is a novel methodology trendy for computational studies; where experts custom crystallographic information about enzyme/protein through protein data bank then dock in contradiction of new micro molecule (Berman et al., 2006). In search of novel breast cancer therapies, repurposed schiff base metal (SB-M) complexes of anticonvulsant agent have been accessed for potential chemopreventive effects. This study involves in the investigation of potential antitumor activity of LTG-SB-M coordinates against MCF-7 breast cancer cell lines in vitro and hormone positive mammary gland tumor of female rats in-vivo. Few LTG-SB-M coordinates were synthesized and reported previously in ACS Omega (Saima et al., 2021) ( $\underline{\text { doi=10.1021/acsomega. } 1 \mathrm{c} 00027 \& \text { ref=pdf })}$.

\section{EXPERIMENTAL}

\subsection{Drugs and Chemicals}

Bovine serum albumin, streptomycin, insulin, trypsin were purchased from Invitrogen (Carlsbad, CA, USA). Trichloro acetic acid (TCA), formaldehyde, pyrogallol solution, isoflurane, DNTB, dimethyl sulfoxide (DMSO), dihydrogen dioxide $\left(\mathrm{H}_{2} \mathrm{O}_{2}\right)$, N-phenylaniline, EDTA, muriatic acid $(\mathrm{HCl})$, carmellose (CMC) and hydrogen sulphate $\left(\mathrm{H}_{2} \mathrm{SO}_{4}\right)$ remained of analytical grades then bought as of native 
dealer agreements by Merck Germany. $N$-methylnitrosourea was purchased from Oakwood Chemicals, United States. Tamoxifen was purchased from Nolvadex, AstraZeneca. ELISA kits for quantification of estradiol E2 and progesterone were purchased from Perkin Elmar Health Sciences, Inc., United States.

\subsection{Molecular modeling}

\subsubsection{Receptor and ligand selection}

The reported three dimensional (3D) crystal structures of enzymes located on estrogen receptor alpha (ER1), estrogen receptor beta (ER2), progesterone receptor (PR) as well as dihydrofolate reductase (DHFR) salvaged from Protein Data Bank (PDB) through PDBID: 3ERD, 1U3S, 4OAR, and 3GHW respectively; (https://www.rcsb.org/structure/3ERD), (https://www.rcsb.org/structure/1U3S), ( (https://www.rcsb.org/structure/3GHW) for anticancer potential. Dual (2D) assemblies of LTG-SB-M complexes were modulated through ACD/Chem Sketch software; which was saved by way of MDL folder. MDL folder was 3D protonated then energy minimized toward PDB with Open Babel GUI (Morris et al., 2009). Two dimensional conformational assemblies of micro molecule were presented in Table 1. 3D crystal assemblies of 3ERD, 1U3S, 4OAR, and 3GHW were modelled by means of Auto Dock Tools 1.5.6; while removing impurities, add up hydrogen and charges. Protein was saved in its corresponding PDBQT file arrangement intended for small molecule connections (Yang et al., 2013). The finest dynamic area of protein remained assured by aiming binding spot by amino acid deposits complexed toward micro molecule (Ebrahimipoura et al., 2015).

\subsubsection{Homology modelling}

Computer assisted design of drug offers the podium to comprehend the enzyme plus micro molecule connections. Docking was deep-rooted computational technique; forecast ligand connections at receptor site (Mahmoud et al., 2020). Docking and scoring of $3 \mathrm{GHW}$, 3ERD, 1U3S, and 4OAR enzymes were figured by Auto dock software 4.2; it simulates 
binding orientations of micro molecule about different receptors designed for anticancer potential then stimulates binding spots of docked fragment using Lamarckian Genetic Algorithm (LGA). Grid box set on 110x100x100 $\AA$ alongside $\mathrm{X}, \mathrm{Y}$ as well as Z axis; through grid spacing of $0.375 \AA$ near identification of binding area of micro molecule. Auto dock parameters used in this study were: cross-over mode of genetic algorithm=2 points, number of energy evaluations $=250000$, population size $=150$. The inflexibility limits were established for protein/enzyme possessing micro molecule flexible. Ten cropped conformations remained after macromolecule-micro molecule docking on 3GHW, 3ERD, $1 \mathrm{U} 3 \mathrm{~S}$, and 4OAR receptors. Finest conformation from each target enzyme was selected on the basis of least energy of binding amongst numerous bioactive orientations created through numerous connections. Cluster investigation of protein binding positions by means of least energy of binding further discovered by means of molecular graphic software Pymol, protein plus as well as protein-ligand interacting profile (PLP) software (Poureshghi et al., 2017; Mahmoud et al., 2020)

\subsubsection{Validation of Model}

The consistency of docking program remained authenticated through re-docking technique; in both cases the co-crystallize ligands were redocked in the active site of enzyme. Root mean square deviation (RMSD) then calculated and in all cases RMSD value of $<2.0 \AA$ was considered accurate in predicting binding orientation of ligand (Jabeen et al., 2018).

\subsection{In-vitro anticancer studies}

Anticancer potential of complexes was assessed in 96-well flat-bottomed micro plates by means of standard calorimetric assay on MTT (3-[4, 5-dimethylthiazole-2-yl]-2, 5diphenyl-tetrazolium bromide) (Venugopal et al., 2017; Saima et al., 2021). 


\subsubsection{Cell culture}

Human BC cell lines (MCF-7) were obtained from the American Type Culture Collection (ATCC, Minnesota, USA). Cells were cultured in EMEM with 10\% fetal bovine serum, $1 \%$ penicillin-streptomycin and incubated with $5 \% \mathrm{CO} 2$.

\subsubsection{Cytotoxic assay}

MCF-7 cells were grown in Eagles Minimum Essential Medium (EMEM), containing $10 \%$ fetal bovine serum (FBS), $1 \%$ streptomycin, $0.1 \mathrm{mM}$ non- essential amino acid, $10 \mu \mathrm{g} / \mathrm{ml}$ insulin, and $1 \mathrm{mM}$ sodium pyruvate in $75 \mathrm{~cm}^{2}$ flasks, maintained the temperature at $37^{\circ} \mathrm{C}$ in $5 \% \mathrm{CO}_{2}$ atmosphere with $95 \%$ air and $100 \%$ relative humidity.

The monolayer cells were detached with warm trypsin $2-3 \mathrm{ml}(0.25 \%)$ and $0.53 \mathrm{mM}$ ethylene diamine tetra acetic acid (EDTA) to make single cell suspensions. The viable cells were counted using a hemocytometer. When layer of MCF-7 cells is separated, then $10 \mathrm{ml}$ of complete growth medium was added in order to neutralize trypsin to flask; suspend the cells through vigorous pipetting. Aspirate growing medium suspension from tube. Again suspend MCF-7 cell pellet in 10ml new growing medium. Cultured cells with the concentration of $6 \times 10^{4}$ cells/ml was prepared and seeded (100 $\mu \mathrm{L} /$ well) onto 96-well plates. After overnight incubation, medium was removed and $200 \mu \mathrm{L}$ of fresh medium was added with different concentrations of compounds (1-30 $\mu \mathrm{M})$. After $48 \mathrm{hrs}, 200 \mu \mathrm{L}$ MTT $(0.5 \mathrm{mg} / \mathrm{ml})$ was added to each well and incubated further for $4 \mathrm{hrs}$. Subsequently, $100 \mu \mathrm{L}$ of DMSO was added to each well (Wang et al., 2014). The extent of MTT reduction to formazan within cells was calculated by measuring the absorbance at $570 \mathrm{~nm}$, using a micro plate reader (Spectra Max plus, Molecular Devices, CA, USA). The cytotoxicity was recorded as concentration causing 50\% growth inhibition (IC50) for MCF-7. The percentage inhibition was calculated by using the following formula:

$\%$ inhibition $=100-(($ mean of O.D of test compound - mean of O.D of negative control)/ (mean of O.D of positive control - mean of O.D of negative control) X 100). 
The results (\% inhibition) were processed by using Soft- Max Pro software (Molecular

Device,

USA).

\subsection{In-vivo cytotoxicity}

\subsubsection{Experimental Animals}

Female Wistar rats (10-12 week old); weighing 100-250 g were retained in ironic cages ( $\mathrm{n}=8)$ maintained at $25 \pm 3^{\circ} \mathrm{C}$; with relative humidity of $60 \pm 10 \%$ in 12 -hr light/dark cycle. Rats had free access to food and water (Adedoin et al., 2019).

\subsubsection{Ethical Committee}

The investigational protocols were approved by Research and Ethical Committee (REC) of the

Riphah Institute of Pharmaceutical Sciences, Islamabad-Pakistan, with REC/RIPS/2019/09 ruled under the arrive guide lines (Annexure Attached). All methods were performed in accordance with the relevant guidelines and regulations.

\subsubsection{Experimental protocol}

Forty (40) Wistar rats (female) remained allotted hooked on five collections of 8 rats respectively. Animals stayed for duration of two weeks to adapt laboratory conditions formerly to experimentation. Group I served as normal control and received normal saline, Group II received NMU (50 mg/kg), Group III received tamoxifen, whereas; Group IV and V received LTG-SB-M complex at dose of $100 \mathrm{mg} / \mathrm{kg}$ body weight, for 15 consecutive days. NMU (single dose) was injected intraperitoneally to rats; at age of 5, 9 and 13 weeks with interval of 3-weeks.

\subsubsection{Tissues preparation}

Rats were sacrificed after $24 \mathrm{hrs}$ of the last dose for removal of mammary glands. The glands were washing away by ice-cold solution of KCL (1.15\%) for removal of blood stain, dried out then evaluated. Afterwards; fix segment of mammary gland in $10 \%$ formaldehyde for histopathological studies. Remaining fragment of gland remained homogenized in four volumes of phosphate buffer $(50 \mathrm{mM}),(\mathrm{pH}=7.4)$ then centrifuged by 
10,000rpm, duration of $15 \mathrm{~min}$ at $4{ }^{\circ} \mathrm{C}$ to acquire supernatant liquid; designed for biochemical analysis.

\subsubsection{Serum preparation}

The blood of animal was congregated from heart in plain centrifuge tubes then was permitted to coagulate intended for $1 \mathrm{hr}$. Serum preparation remained carried out through centrifugation on $4000 \mathrm{rpm}$ for $20 \mathrm{~min}$ in a Beckman bench centrifuge. The pure supernatant was used for approximation of serum enzymes.

\subsection{Biochemical assays}

\subsubsection{Total protein, bilirubin, Alanine and aspartate aminotransferases determination}

Kits for determination of liver functioning parameters i.e., Bilirubin, Total protein, ALT, AST and ALP enzyme levels were purchased from crescent diagnostics, KSA. Following the standard procedure, serum sample was added by respective enzyme reagent (mixture 1) [sodium carbonate $\left(\mathrm{Na}_{2} \mathrm{CO}_{3}\right) 2 \%$, sodium hydroxide $(\mathrm{NaOH}) 0.1 \mathrm{~N}$, sodium potassium tartrate $1 \%$, copper sulphate (CuSO4) $0.5 \%$ ] then incubation was done for 10 min at $37^{\circ} \mathrm{C}$ followed by addition of substrate reagent (mixture 2) [2 N Folin phenol] with subsequent incubation of $30 \mathrm{~min}$ at $37^{\circ} \mathrm{C}$. The resultant mixture was examined in chemistry analyzer that measured the absorbance and quantified liver enzyme levels. Then absorbance was noted by means of a UV-visible spectrophotometer at $660 \mathrm{~nm}$.

\subsubsection{Renal function test (RFT)}

Kits for determination of renal functioning parameters i.e., creatinine and urea levels; were purchased from crescent diagnostics, KSA. Following the standard procedure, serum sample was added by respective enzyme reagent (reagent 1) followed by addition of substrate reagent (reagent 2). The resultant mixture was incubated and examined in chemistry analyzer that measured the absorbance and quantified renal enzyme levels.

\subsubsection{Evaluation of catalase activity}


Action of catalase was resolute as a result of the decomposition of dihydrogen dioxide $\left(\mathrm{H}_{2} \mathrm{O}_{2}\right)$ into water and oxygen by method reported by Hira et al. (2019). Precisely, $1.95 \mathrm{ml}$ of buffer solution of phosphate ( $\mathrm{pH} 7.4), 0.05 \mathrm{ml}$ supernatant from tissue, then $1 \mathrm{ml}(30$ $\mathrm{mM}$ ) dihydrogen dioxide mixed by means of different steps. The absorbance remained documented by UV-visible spectrophotometer at 240nm.

\subsubsection{Activity of superoxide dismutase (SOD)}

SOD remained resolute rendering toward Kim et al. (2016). The blend remained completed through addition of $10 \% \mathrm{w} / \mathrm{v}$ mammary tissue homogenate $0.1 \mathrm{ml}$, solution of pyrogallol $0.1 \mathrm{ml}(\mathrm{pH}=7.4)$, then potassium phosphate buffer $2.8 \mathrm{ml}(\mathrm{pH}=7.4)$ within a test tube. Absorbance of blend remained recorded at $325 \mathrm{~nm}$ by means of UV-visible spectrophotometer (Shamadzo, Japan).

\subsubsection{Reduced glutathione (GSH)}

Reduced glutathione was resolute rendering to Hira et al. (2019). A mammary gland homogenate $(1 \mathrm{ml})$ deproteinized by adding in trichloroacetic acid $1 \mathrm{ml}(10 \%)$ in a test tube . Then $4 \mathrm{ml}$ solution of phosphate buffer $(\mathrm{pH}=7.4)$ as well as 5,5- dithiobis-2nitrobenzoic acid reagent $(0.5 \mathrm{ml})$ were stepwise added to the portions of the supernatant. Measure the absorbance at $412 \mathrm{~nm}$ by mean of UV-visible spectrophotometer.

\subsubsection{Determination of total sulfhydryl (TSH) level}

Total sulfhydryl (TSH) intensities analyzed by the reported method of Ellman (1951) and Adefisan et al. (2019). Reaction blend comprises of $1 \mathrm{ml}$ mammary gland homogenate and 5,5'-dithiobis-2-nitrobenzoic acid (DTNB) reagent (Ellman's Reagent) to give a relatively stable (yellow) color. The resultant chromophore product was formed; possesses the molar absorption at $412 \mathrm{~nm}$.

\subsubsection{Assessment of percentage DNA disintegration}

DNA disintegration remained estimated by $\mathrm{Wu}$ et al. (2005) and Adefisan et al. (2019) methods. The tissue from mammary gland of rats remained homogenized by 10 volumes of 


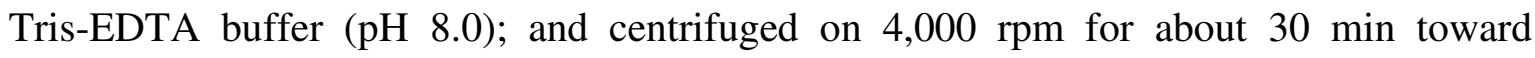
detachment of complete chromatin (pellet A) from disintegrated chromatin (supernatant name B). Pellet (A) remained suspended by mean of Tris-EDTA buffer at $\mathrm{pH}$ 8.0. Concisely, $0.5 \mathrm{~mL}$ portions of each sample (supernatant/ pellet) remained positioned within distinct test tubes then $1.5 \mathrm{~mL}$ recently set mixture of diphenylamine supplemented toward individual test tube. Remained incubate for $20 \mathrm{hrs}$ at $37{ }^{\circ} \mathrm{C}$. Mixture absorbance was estimated at $620 \mathrm{~nm}$. The percentage DNA fragmentation was calculated by means of formula:

$\%$ fragmented DNA $=$ Absorbance of supernatant $/$ Absorbance of pellet + Absorbance of supernatant x 100

\subsubsection{Enzyme-Linked Immunosorbent Assay (ELISA)}

An ELISA kit was used for quantification of estradiol as well as progesterone (PR) in mammary tissues of rat. In short, the well plate remained covered by antigen (serum), in addition to principal antibody was introduced, through adding secondary conjugated enzyme antibody used for antigen-antibody-enzyme-antibody complex. The reaction was stopped by the addition of solution of $\mathrm{H}_{2} \mathrm{SO}_{4}$; absorption was measured by microplate reader (Diamate Bio-Tech., UK). Color change was observed at $450 \mathrm{~nm}$ spectrophotometrically.

\subsubsection{Histopathological Studies}

Mammary gland sections secure in $10 \%$ formaldehyde; remained dehydrated in $95 \%$ ethanol then washed with xylene earlier to fix with paraffin. Longitudinal microcomputer segments $(3-4 \mu \mathrm{m})$ were fixed then stained by hematoxylin then eosin $(\mathrm{H} \& \mathrm{E})$ dye. The slides then studied by histopathologist; ignorant of the treatment groups; under a light microscope.

\subsection{Statistical Analysis}


Altogether the results were signified as mean \pm S.E.M. The variance analysis then executed, wherever applicable one-way ANOVA followed by post-hoc Dunnet's test remained applied by means of Graph pad Prism-9. $* \mathrm{P}<0.05, * * \mathrm{P}<0.01$ and $* * * \mathrm{P}<0.001$ measured by way of significance level, short to moderate substantial as well as extremely substantial correspondingly.

\section{RESULTS}

\subsection{Molecular docking}

Appropriate justification of the process of antitumor effects of LTG-SB-M coordinates; molecular docking analysis was performed at various protein receptors (ER $\alpha$, ER $\beta$, and PR). Enzyme-ligand interactions and authentication of enzyme models was accomplished through Protein Ligand interaction Profile (PLP), Protein plus, as well as Pyrex. Proteinligand interacting properties of multiple enzymes correspondingly interacting amino acid remains were described in Table 1.

Table 1. Receptor-protein interactions with different ligands

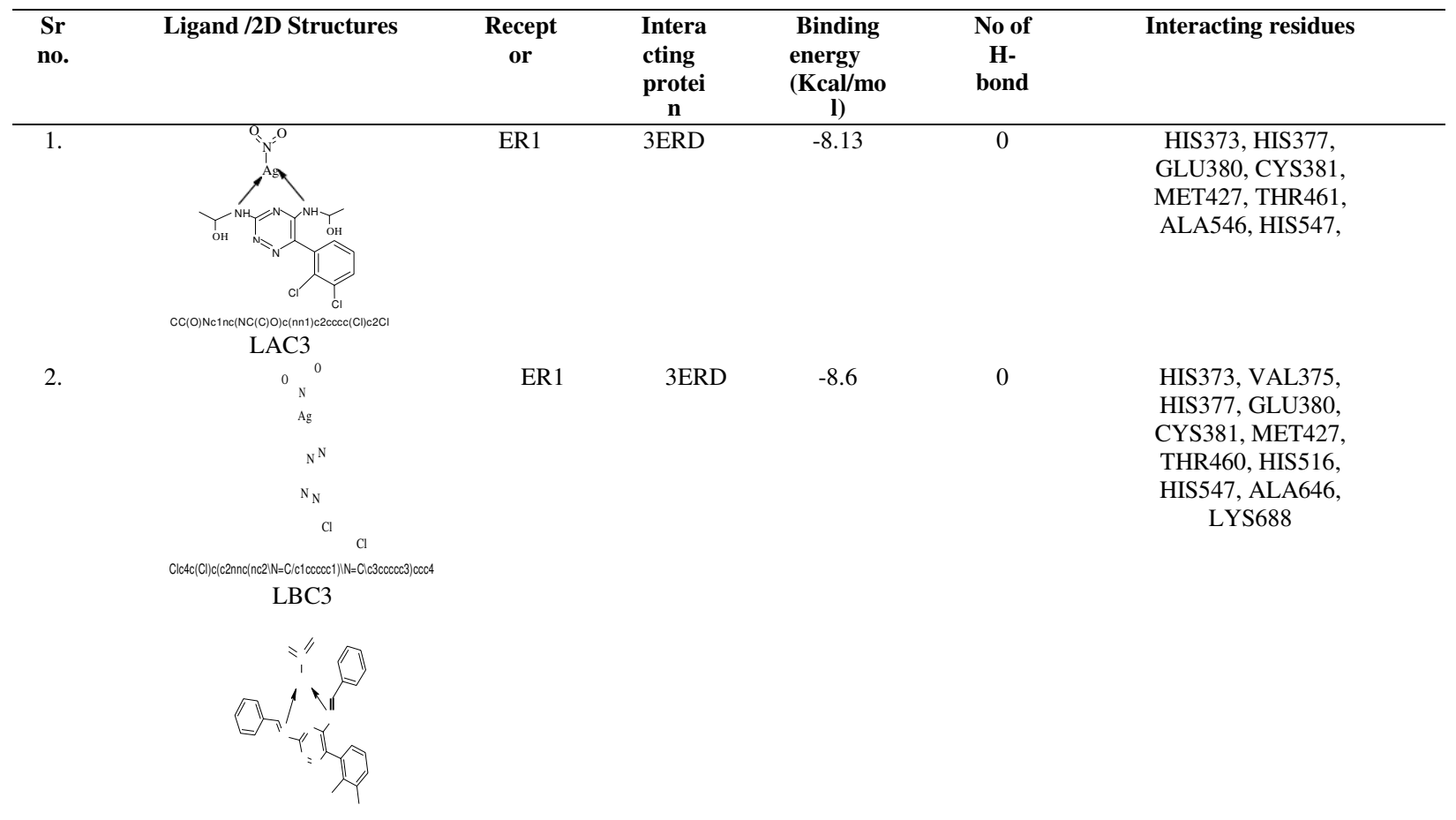


3.

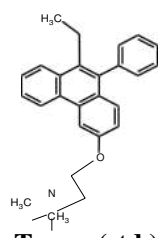

4.

Tamo. (std.)

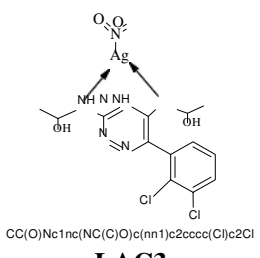

5.

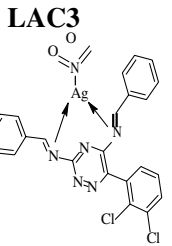

$\mathrm{Clc} 4 \mathrm{c}(\mathrm{Cl}) \mathrm{c}(\mathrm{c} 2 \mathrm{nnc}(\mathrm{nc} 2 \mathrm{IN}=\mathrm{C} / \mathrm{c} 1 \mathrm{ccccc} 1) \mathrm{N}=\mathrm{Clc} 3 \mathrm{ccccc} 3) \mathrm{ccc}$

6.

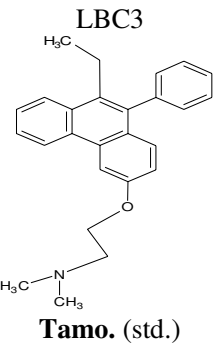

7.

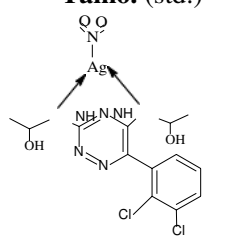

$\mathrm{CC}(\mathrm{O}) \mathrm{Nc1} 1 \mathrm{nc}(\mathrm{NC}(\mathrm{C}) \mathrm{O}) \mathrm{c}(\mathrm{nn} 1) \mathrm{c} 2 \mathrm{cccc}(\mathrm{Cl}) \mathrm{c} 2 \mathrm{Cl}$

8.

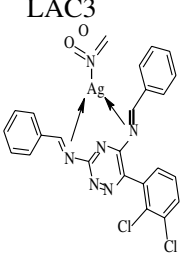

PR

4OAR

$-8.18$

$-10.36$

ER2

1U3S

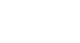

LEU298, THR299,

ALA302, GLU305,

MET336, LEU339,

LEU343, ARG346, PHE356, LEU476,

LEU491,

PR

4OAR

$-9.36$

0

4OAR

$-9.47$

0

GLN725, SER728,

VAL729, TRP732,

LEU758, GLY762,

TRP765, ARG766, GLU695, PHE818, LYS822

10. 1

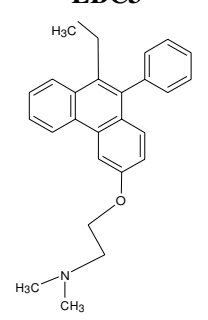

Tamo. (std.)

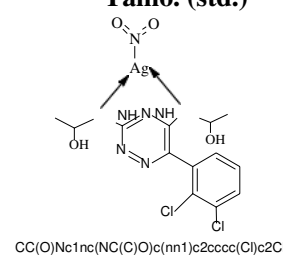

DHFR

3GHW

$-9.08$

0

ALA9, ILE16, GLY27, GLY30, LEU32, LYS55, THR56, SER59, SER116, GLY117, TYR121, 
11.

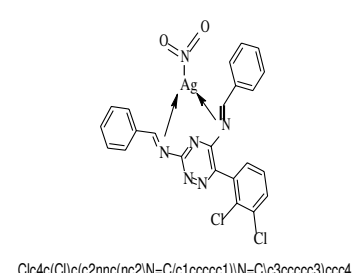

12.

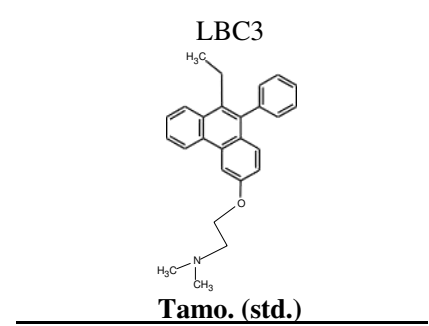

DHFR

$3 \mathrm{GHW}$

$-9.08$

DHFR

$3 \mathrm{GHW}$

$-8.99$

0

VAL3, ALA9, ILE16, ASP21, LEU22, PHE31, TYR33, PHE34, GLU39, SER59, ILE60

Tamoxifen (Tamo) was used as standard drug designed aimed at antitumor computational analysis; various parameters related to Tamo now revealed in Table 1; by various receptors for breast cancer. The compound LAC3 shows least binding energy of $-9.28 \mathrm{Kcal} / \mathrm{mol}$ at ER2 (1U3S) receptor; along with amino acid remains present in its binding pocket are MET295, LEU339, LEU343, ARG346, PHE356, ILE373, ILE376, PHE377, HIS475, and LEU476 as shown in Figure 1. Tamo being standard for ER2 receptor shows highest affinity with $1 \mathrm{U3S}$ enzyme (binding energy $=-10 \mathrm{Kcal} / \mathrm{mol}$ ); with amino acids involved in the binding pocket of ER2 receptor are LEU298, THR299, ALA302, GLU305, MET336, LEU339, LEU343, ARG346, PHE356, LEU476, and LEU491 as cleared from Figure 2.

On the other hand compound $\mathbf{L B C 3}$ shows greater affinity at PR receptor with least binding energy of $-9.36 \mathrm{Kcal} / \mathrm{mol}$ and amino acid remains complexed on 4OAR enzyme includes LEU718, LEU716, ASN719, GLY722, GLU723, GLN725, MET758, LEU763, PHE778, PHE794, LEU797, and MET799 as demonstrated in Figure 3. Tamo is used to standardize the results at PR (4OAR) receptor; along with binding energy of -9.47 Kcal/mol and amino acid remains are GLN725, SER728, VAL729, TRP732, LEU758, GLY762, TRP765, ARG766, GLU695, PHE818, and LYS822 as shown in Figure 4. Hence, tamoxifen shows strong interaction at all types of protein receptors (ER $\alpha$ (ER1), $\mathrm{ER} \beta$ (ER2), PR and DHFR) than LAC3 and LBC3. 

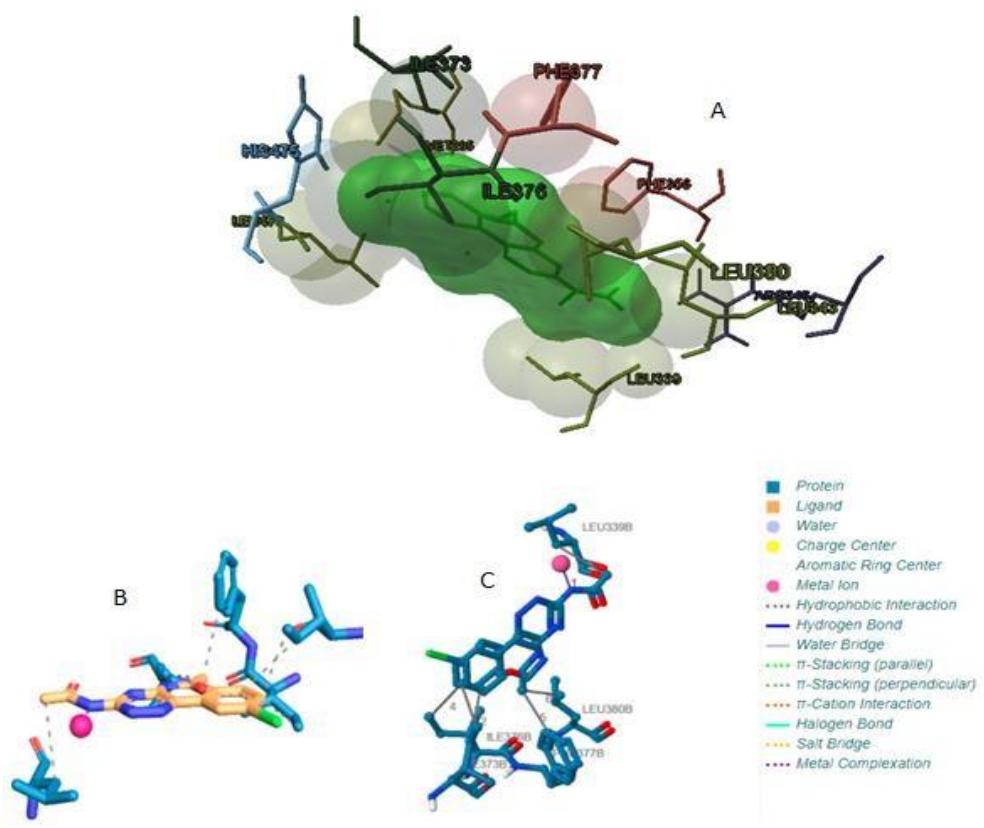

Figure 1. (A) Protein-ligand (LAC3-1U3S) interface (by auto dock) with the least binding energy of $-9.28 \mathrm{kcal} / \mathrm{mol}$ infers more stable docking. (B) Orange colored ligand in the binding pocket of $1 \mathrm{U} 3 \mathrm{~S}$ enzyme; amino acid remains were revealed as blue color with scattered grey lines display hydrophobic connections. (C) Docked structure of LAC3 by modeled 1U3S enzyme (ER2) obtained through protein plus; along with interacting amino acid remains.

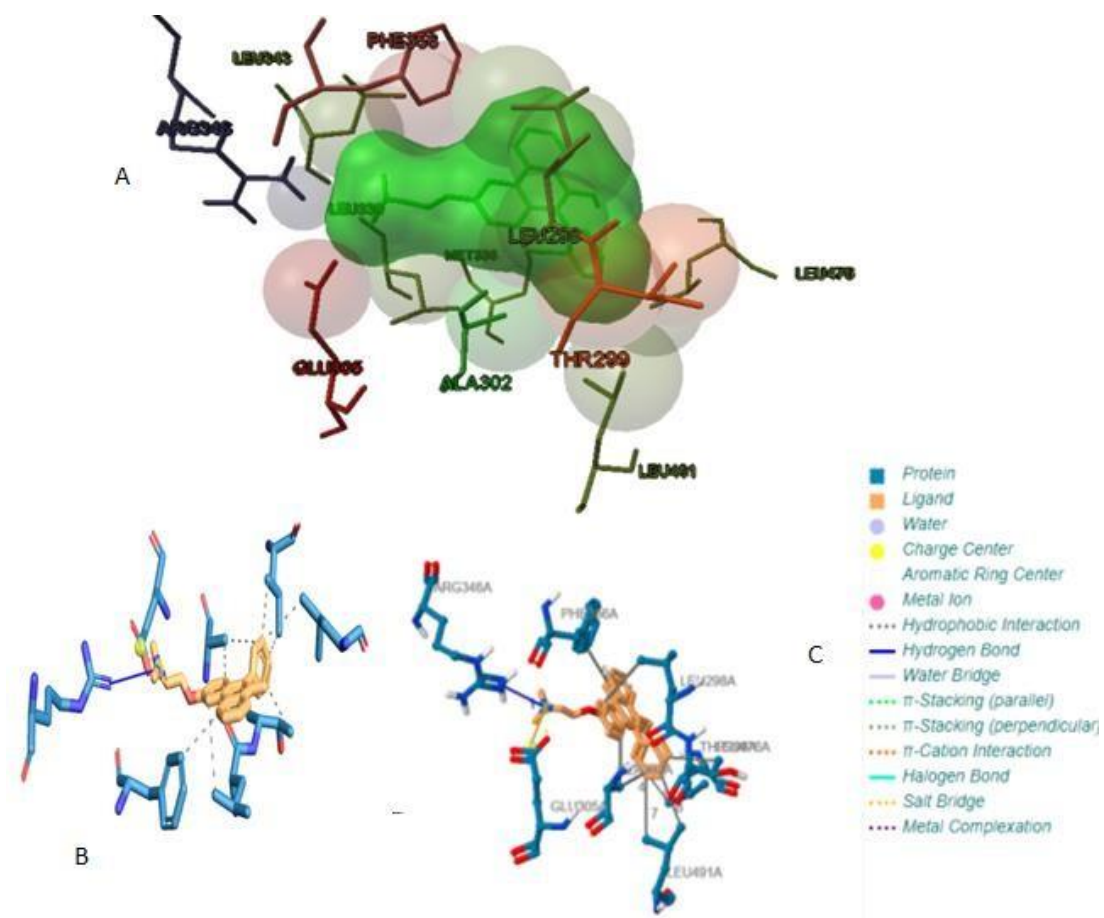


Figure 2. (A) Enzyme-ligand (Tamo-1U3S) interface (by mean of auto dock) with least binding energy of docked compound was found to be $-10.36 \mathrm{kcal} / \mathrm{mol}$; infers steadier docking. (B) Residues presented as blue color with spotted grey lines shows hydrophobic connections within binding pocket of 1U3S enzyme by ligand revealed as orange color. (C) Docked assemblies of tamoxifen by means of modeled $1 \mathrm{U} 3 \mathrm{~S}$ enzyme (ER2) obtained through protein plus; accompanied by interacting amino acid remains.
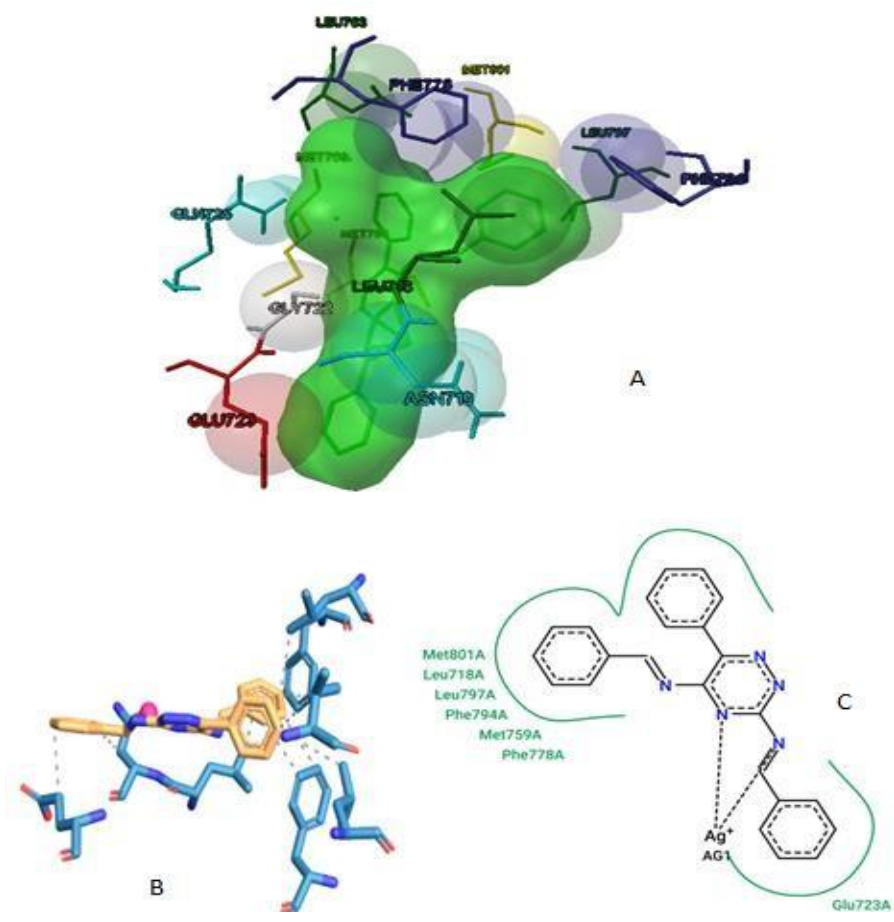

Figure 3. (A) Protein-micro molecule (LBC3-4OAR) collaboration (by auto dock) through least binding energy of docked composite found near $-9.36 \mathrm{kcal} / \mathrm{mol}$. (B) Ligand was revealed in orange color with blue colored residues; spotted grey lines display hydrophobic connections within binding pocket of 4OAR protein obtained by PLP. (C) Docked assembly of LBC3 through 4OAR protein (PR) obtained by protein plus; accompanied by interacting residues of amino acid. 

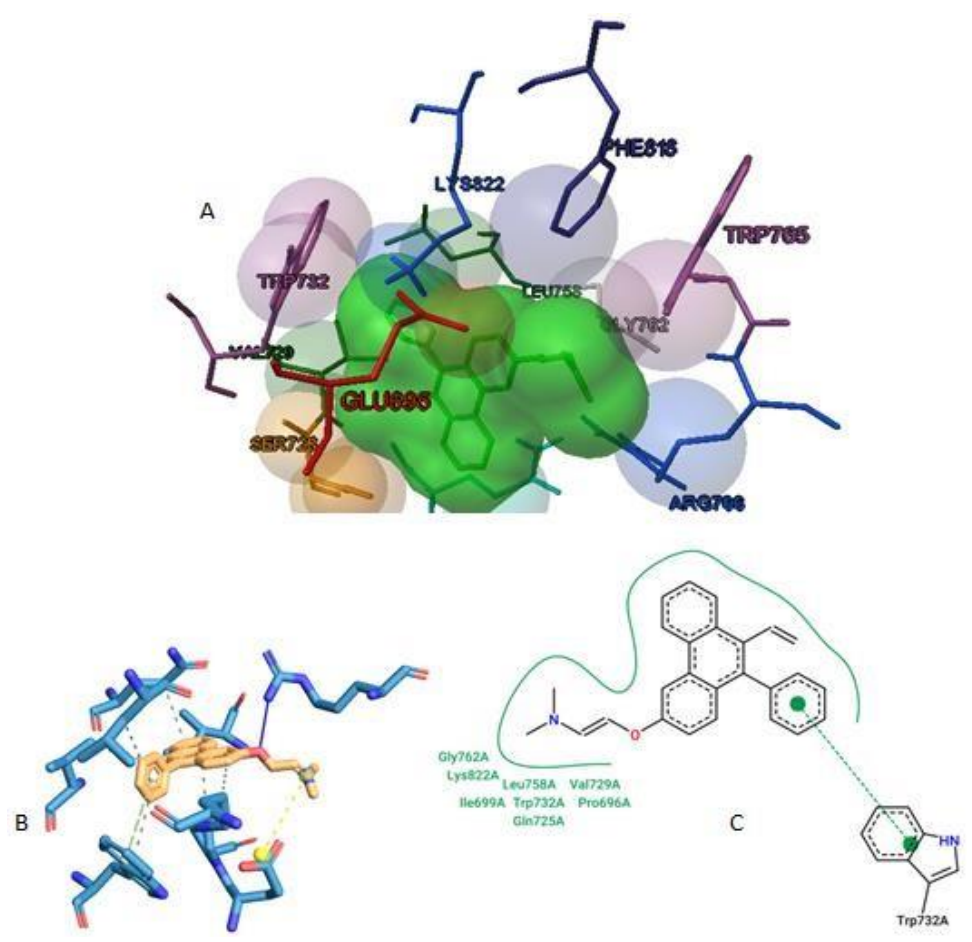

Figure 4. (A)protein-ligand (tamo-4OAR) collaboration (got from auto dock) along with the least binding energy of docked complex was found to be $-9.47 \mathrm{kcal} / \mathrm{mol}$. (B) Ligand displayed in orange color with blue colored residues in coordination with scattered grey lines display hydrophobic connections within binding pocket of 4OAR enzyme obtained by PLP. (C) Docked assembly of tamoxifen by modeled 4OAR protein (PR) obtained by means of protein plus; accompanied by interacting amino acid residues.

\subsection{In vitro Cytotoxicity assay}

Growing reserve effects within cultured human mammary cancer (MCF-7 cell lines) was estimated at a fix dose of $30 \mu \mathrm{M}$ then linked by means of standard doxorubicin as mentioned in Table 2. The calculated half-maximal inhibitory dose of LAC3 and LBC3 was $12.7 \pm 0.25 \mu \mathrm{M}$ and $12.4 \pm 0.39 \mu \mathrm{M}$ respectively 
Table 2. Cytotoxic potential of LAC3 and LBC3 on MCF-7 breast cancer cell lines

\begin{tabular}{cccc}
\hline Code & Conc. $(\boldsymbol{\mu M})$ & $\begin{array}{c}\text { \%inhibition/ } \\
\text { Stimulation }\end{array}$ & IC50 \pm SD \\
LAC3 & $\mathbf{3 0}$ & $\mathbf{1 0 1 . 7}$ & $\mathbf{1 2 . 7 \pm 0 . 2 5}$ \\
LBC3 & $\mathbf{3 0}$ & $\mathbf{1 0 1 . 1}$ & $\mathbf{1 2 . 4 \pm 0 . 3 9}$ \\
$\begin{array}{c}\text { Doxorubicin } \\
\text { (DOX) }\end{array}$ & 30 & 101.2 & $0.90 \pm 0.14$ \\
\hline
\end{tabular}

Data be present by way of mean \pm S.E.M. $\mathrm{P}<0.05$ vs vehicle group; wherever appropriate One Way Anova by Dunnett's post hoc test was applied.

\subsection{In vivo cytotoxicity}

\subsubsection{Effect of LTG-SB-M complex on organ weight and biochemical parameters} (Total protein, bilirubin, Alanine and aspartate aminotransferases, albumin, globulin, urea, and creatinine)

The effect of LTG-SB-M complexes on organ (mammary gland) mass of NMU treated rats are presented in Table 3. NMU management triggered significant decrease in weight of body in comparison towards control group. In comparison, it considerably ( $p>0.05)$ increase mammary gland mass; however supplementation with LAC3 and LBC3 at a dose of $100 \mathrm{mg} / \mathrm{kg}$ significantly ( $>0.05$ ) reduced the organ weight of rats by $58 \%$ and $61 \%$ respectively. In addition, rats treated with NMU results in significant ( $p>0.05)$ increase in serum alanine aminotransferase (ALT), aspartate aminotransferase (AST), total bilirubin, total protein, albumin, globulin, urea and creatinine as cleared from Table 4 . Though, here remained no considerable $(\mathrm{p}>0.05)$ alterations within alanine aminotransferase activity when treated with NMU; in comparison to other groups (Table 4).

Table 3: Effect of treatments on weight of the mammary gland

\begin{tabular}{cc}
\hline $\begin{array}{c}\text { Treatment } \\
\text { Group }\end{array}$ & $\begin{array}{c}\text { Weight of the } \\
\text { mammary gland }(\mathbf{g})\end{array}$ \\
\hline Control & $0.35 \pm 1.2$ \\
Diseased & $0.62 \pm 3.2$ \\
Standard & $0.33 \pm 1.5^{*}$ \\
LAC3 & $0.425 \pm 1.1$ \\
LBC3 & $\underline{0.395 \pm 1.1^{*}}$ \\
\hline
\end{tabular}

Data are presented as mean $\pm S E M, n=6, p<0.05$ 
Table 4: Consequence of treatments on liver as well as renal function tests in rats treated with NMU

\begin{tabular}{|c|c|c|c|c|c|}
\hline $\begin{array}{l}\text { Biochemical } \\
\text { Parameters }\end{array}$ & Control & Diseased & Standard & LAC3 & LBC3 \\
\hline Bilirubin & $1.1 \pm 0.3$ & $0.7 \pm 1.2$ & $0.8 \pm 1.2$ & $0.8 \pm 1.2$ & $\begin{array}{c}0.9 \pm \\
0.1\end{array}$ \\
\hline ALT & $40 \pm 1.2$ & $111 \pm 3.2$ & $93 \pm 4.1^{*}$ & $\begin{array}{l}96 \pm \\
2.2^{*}\end{array}$ & $\begin{array}{l}84 \pm \\
1.1^{* * *}\end{array}$ \\
\hline AST & $125 \pm 0.8$ & $94 \pm 2.1$ & $54 \pm 3.2^{* *}$ & $85 \pm 1.2$ & $\begin{array}{c}86 \pm \\
0.5\end{array}$ \\
\hline ALP & $127 \pm 2.1$ & $235 \pm 1.3$ & $\begin{array}{l}199 \pm \\
2.3 * *\end{array}$ & $\begin{array}{l}196 \pm \\
2.8^{* *}\end{array}$ & $\begin{array}{c}139 \pm \\
1.2 * * *\end{array}$ \\
\hline $\begin{array}{c}\text { Total } \\
\text { proteins }\end{array}$ & $6.2 \pm 1.3$ & $7.4 \pm 3.2$ & $6.8 \pm 0.5$ & $6.9 \pm 1.2$ & $\begin{array}{c}6.9 \pm \\
0.2\end{array}$ \\
\hline Albumin & $3.8 \pm 2.3$ & $4.1 \pm 0.5$ & $4.0 \pm 1.0$ & $3.7 \pm 0.5$ & $\begin{array}{c}4.10 \pm \\
0.5\end{array}$ \\
\hline Globulin & $2.7 \pm 0.9$ & $3.3 \pm 1.2$ & $2.8 \pm 0.2$ & $3.2 \pm 1.2$ & $\begin{array}{c}2.9 \pm \\
1.2\end{array}$ \\
\hline A/G Ratio & $1.26 \pm 1.3$ & $1.24 \pm 3.1$ & $1.42 \pm 0.3$ & $\begin{array}{c}1.15 \pm \\
0.2\end{array}$ & $\begin{array}{c}1.367 \pm \\
1.3\end{array}$ \\
\hline Urea & $39 \pm 0.8$ & $45 \pm 1.2$ & $44 \pm 1.2$ & $34 \pm 1.0^{*}$ & $\begin{array}{l}34 \pm \\
1.8^{*}\end{array}$ \\
\hline Creatinine & $0.9 \pm 1.2$ & $0.7 \pm 1.2$ & $0.8 \pm 1.3$ & $0.9 \pm 0.1$ & $\begin{array}{c}0.8 \pm \\
1.0 \\
\end{array}$ \\
\hline
\end{tabular}

Data are presented by way of mean $\pm \mathrm{SEM}, \mathrm{n}=3$. $* \mathrm{P}<0.05$, **P<0.01 \& ***P<0.001 was given when associated by means of diseased collection.

\subsubsection{Consequence of LTG-SB-M complex on oxidative stress biomarkers in NMU treated rats}

Biochemical markers like SOD, GSH, MDA, and catalase activity were determined to estimate the efficacy of LTG-SB-M complexes in oxidative stress. Treatment with LAC3 and LBC3 at $100 \mathrm{mg} / \mathrm{kg}$ dose significantly diminished the toxicity of NMU on the oxidative stress biomarkers. Results indicate significantly increased levels of catalase, GSH and MDA activity as compared with control group (Table 5). Here remained certainly not any significant $(\mathrm{p}>0.05)$ difference in movement related to mammary SOD when treated with NMU relative to others (Table 
Table 5: Estimation of treatments on oxidative stress biomarkers in mammary glands of rats treated with NMU

\begin{tabular}{|c|c|c|c|c|c|}
\hline Treatment & $\begin{array}{c}\text { SOD } \\
(\mu \mathrm{g} / \mathrm{mg} \\
\text { of tissue } \\
\text { protein) }\end{array}$ & $\begin{array}{c}\text { GSH } \\
\text { ( } \mathrm{mmole} / \mathrm{mg} / \mathrm{min}\end{array}$ & $\begin{array}{c}\text { Catalase } \\
(\mu \mathrm{g} / \mathrm{mg} \text { of } \\
\text { tissue } \\
\text { protein })\end{array}$ & $\begin{array}{c}\text { MDA } \\
\text { ( } \mu \text { mole/ } \\
\text { mg of } \\
\text { tissue } \\
\text { protein) }\end{array}$ & $\begin{array}{c}\text { Total } \\
\text { Protein } \\
\text { ( } \mu \text { g/mg of } \\
\text { tissue } \\
\text { protein) }\end{array}$ \\
\hline${ }^{t}$ Control & $3.2 \pm 1.4$ & $0.7 \pm 0.5$ & $23.5 \pm 1.5$ & $\begin{array}{c}0.01 \pm \\
0.3\end{array}$ & $13.3 \pm 2.3$ \\
\hline Diseased & $1.0 \pm 0.6$ & $0.1 \pm 0.9$ & $19.8 \pm 2.3$ & $0.6 \pm 1.3$ & $11.4 \pm 2.6$ \\
\hline Standard & $\begin{array}{c}3.8 \pm \\
1.3 * * *\end{array}$ & $0.5 \pm 1.1 * *$ & $\begin{array}{l}124.5 \pm \\
0.5 * * *\end{array}$ & $0.01 \pm 0.5$ & $\begin{array}{c}23.1 \pm \\
1.2^{*}\end{array}$ \\
\hline LAC3 & $\begin{array}{c}2.67 \pm \\
1.2\end{array}$ & $0.67 \pm 1.2^{* *}$ & $\begin{array}{c}50.6 \pm \\
1.3 * * *\end{array}$ & $\begin{array}{c}0.14 \pm \\
0.3^{*}\end{array}$ & $12.6 \pm 2.7$ \\
\hline LBC3 & $\begin{array}{c}2.20 \pm \\
0.5\end{array}$ & $0.5 \pm 0.9 * *$ & $\begin{array}{l}49.5 \pm \\
1.4 * * *\end{array}$ & $\begin{array}{c}0.15 \pm \\
0.9^{*}\end{array}$ & $13.6 \pm 1.2$ \\
\hline
\end{tabular}

Data are signified as mean $\pm \mathrm{SEM}, \mathrm{n}=3 . * \mathrm{P}<0.05, * * \mathrm{P}<0.01 \& * * * \mathrm{P}<0.001$ was given when associated to bizarre collection.

\subsubsection{Consequence of LTG-SB-M complex on DNA fragmentation and total sulfhydryl (TSH) levels in NMU treated rats}

There was no significant $(\mathrm{p}>0.05)$ difference observed within DNA disintegration in NMU-treated group comparative toward others (Table 6). However, treatment with LAC3 and $\mathbf{L B C 3}$ at $100 \mathrm{mg} / \mathrm{kg}$ dose significantly weakened the toxicity associated with NMU on TSH levels as associated to others.

Table 6: Effect of treatments on mammary gland DNA fragmentation and total sulfhydryl in rats

\begin{tabular}{ccc}
$\begin{array}{c}\text { Treatment } \\
\text { Groups }\end{array}$ & $\begin{array}{c}\text { DNA } \\
\text { Fragment }(\%)\end{array}$ & $\begin{array}{c}\text { Total Sulfhydryl } \\
(\boldsymbol{\mu m o l} / \mathbf{L})\end{array}$ \\
\hline Control & $39.3 \pm 0.5$ & $0.53 \pm 0.3$ \\
Diseased & $58.2 \pm 3.2$ & $0.23 \pm 0.1$ \\
Standard & $44.2 \pm 1.3$ & $0.4 \pm 0.3$ \\
LAC3 & $42.5 \pm 2.2$ & $0.49 \pm 0.5$ \\
LBC3 & $52.9 \pm 2.1$ & $0.45 \pm 0.6$ \\
\hline Data are presented as mean + SEM, $\mathrm{n}=3$. &
\end{tabular}

\subsubsection{Effect of LTG-SB-M complex on Protein Analysis by ELISA}

Estimation of estrogen and progesterone positive tumor by ELISA kit technique designated that LAC3 and LBC3 significantly reduced levels in rat organ. The reduction might be due to fewer aggregation plus plaque creation within breast cells (Figure 5 and 6). 


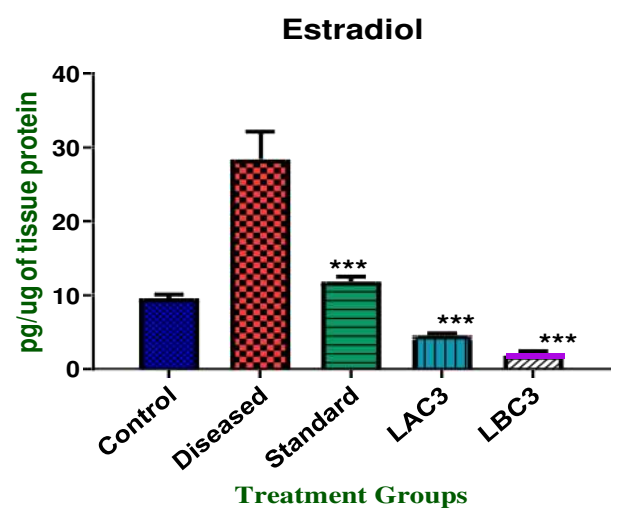

Figure 5. Effect of treatments on level of Estradiol in mammary glands of NMU treated rats

**** $<0.001$ when associated by way of unhealthy group.

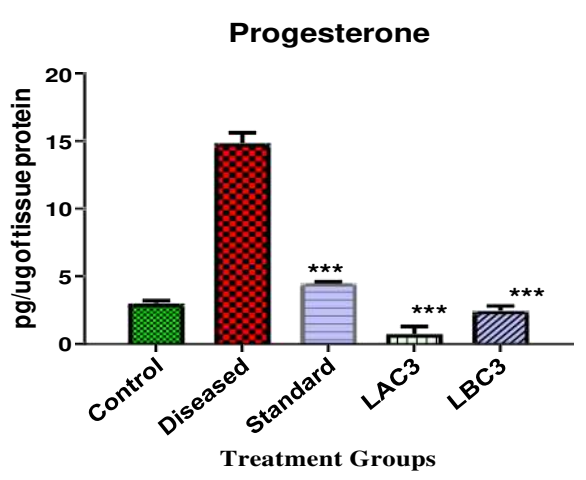

Figure 6. Consequence of treatments of NMU on Progesterone levels in mammary glands *** $\mathrm{P}<0.001$ when associated by means of diseased group

\subsubsection{Histology of mammary gland in NMU treated rats}

Histopathological discoveries of all investigational group animals remained associated for NMU-induced tissue irregularities with new compound treatment modifications; these findings were presented in Figure 7. Histology of normal mammary gland displays the occurrence of regular epithelia, duct, mammary adipose tissue and stroma; whereas rats treated with NMU $(5 \mathrm{mg} / \mathrm{kg})$ presents temperate increase in intra-ductal fibrous tissues and benign fibro adenomas along with some characteristics of papillary carcinoma. In addition; tamoxifen $(5 \mathrm{mg} / \mathrm{kg})$ treatment showed normal stroma and epithelial tissues. However, 
groups treated with $\mathbf{L A C 3}$ and $\mathbf{L B C 3}$ at $100 \mathrm{mg} / \mathrm{kg}$ dose possess usual stroma with small intensification in peri-ductal stringy tissues no benign fibro adenomas (Figure 7).

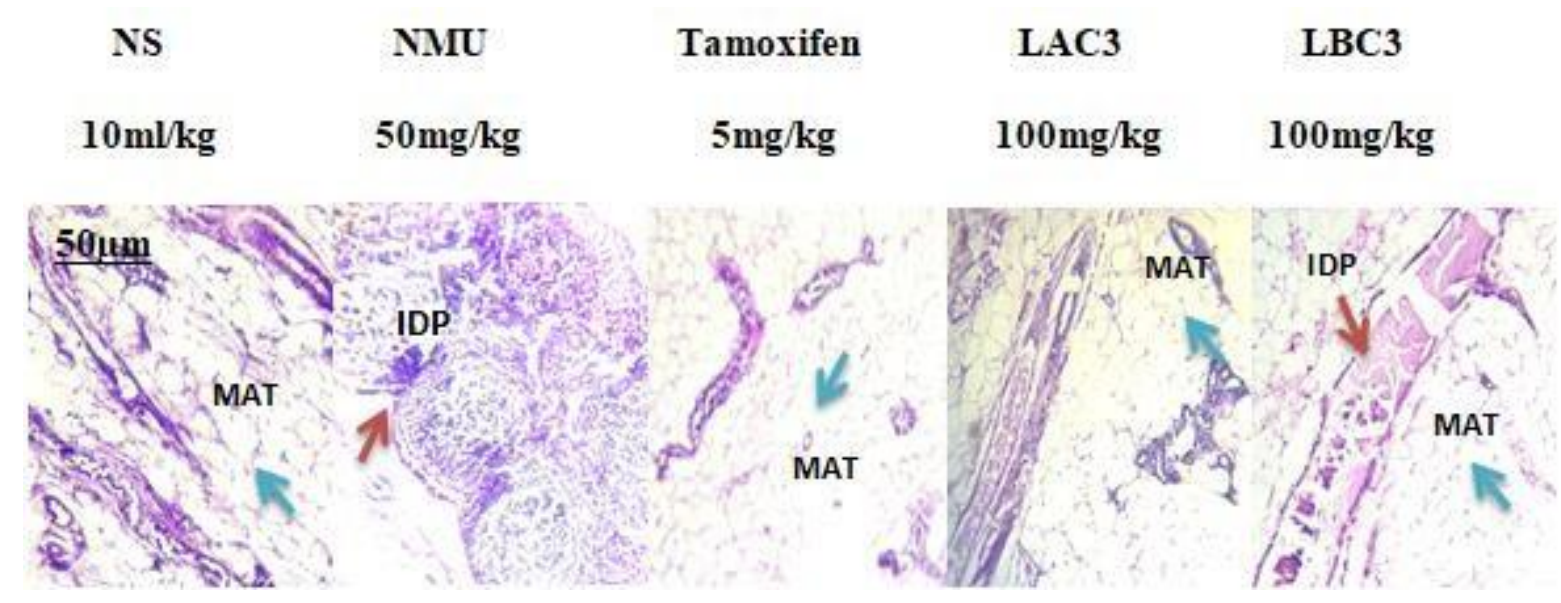

Figure 7. Effect of LAC3 and LBC3 treatment in female rats mammary gland histoarchitecture against toxicity induction by NMU. MAT= mammary adipose tissue shown by blue arrow; IDP= intraductal proliferations shown by red arrows

\section{DISCUSSION}

These pharmacological findings were not stated earlier; due to versatile pharmacophore of schiff bases; they accommodate metals quite easily. This study was the first report of LTGSB-M complexes with potent anticancer studies (in-vitro and in-vivo). Computational studies presents good binding interactions of LAC3 at ER2 receptor and LBC3 at PR receptor; but not better than standard anticancer drug tamoxifen. All tested complexes showed inadequate cytotoxicity against MCF-7 cell lines except LAC3 and LBC3. Potent cytotoxic agents were promoted to in-vivo breast cancer studies.

In present study protocol, it is clearly demonstrated that compound LAC3 and LBC3 possess potent antitumor effect against mammary gland toxicity induced by NMU in investigational rats. The substantial upsurge in weight of mammary gland, as well as improved appearance of estrogen and progesterone receptor proteins clearly shows the aptitude of NMU in the direction of pledging development of carcinogenesis within mammary tissues of rats. Development of mammary gland pretentious through three chief hormones: progesterone, estrogen, as well as prolactin (Aqil et al., 2017/21). To persuade 
appearance of PR in ER+ cells estrogen is required; hereafter it is challenging towards isolation of progesterone effect alone from estrogen (Lange and Yee, 2008/22). The ability of LAC3 and LBC3 to mitigate NMU-induced loss in body mass in rats further approves its defensive role. Significant modification of structures' organizations must also be taken into account when examining the route by which LAC3 and LBC3 improves mammary tumor. In current findings, significant raise of serum total bilirubin levels then aspartate aminotransferase activities further confirmed that hepatic cellular integrity remained conceded in NMU-treated rats. Alluringly, these fallouts revealed that compound LAC3 and $\mathbf{L B C 3}$ were able to reinstate the indices to standard values. This study also attempts to fill the need for an in depth histopathological analysis of the mammary gland in Wistar rats after exposure to low doses of NMU. Though, a number of microscopic abnormalities were apparent in whole mounted mammary glands collected from the low dose animals while histological analysis showed that these ranged from simple ductal hyperplasia, stroma and peri-ductal fibrous tissues. This substantial decrease in illness trademarks is the vehicle of LAC3 antitumor competences towards countering breast malignancy then demonstrates the likelihood of manipulation intended for forthcoming readings.

\section{Conclusion}

The findings of current studies deduced that some lamotrigine coordinates remained identified as robust anticancer agents; amongst all LAC3 was found to be most significant. Conformational analysis of these derivatives has shown fair correlation between investigational studies in addition to binding energy estimation amongst LAC3 and LBC3. The best compound should further verified on clinical basis.

\section{SUPPORTING INFORMATION}

The Supporting Information is available online. 


\section{ETHICS STATEMENT}

The investigational procedure was endorsed and permitted through research and ethical committee (REC) of the Riphah Institute of Pharmaceutical Sciences, Riphah International University, Islamabad-Pakistan (approval ID: ref. no. REC/ RIPS/2019/09 and Date of Approval: 28th Nov, 2019). The accepted etiquettes remained followed on the way to in vivo cytotoxic activity in rat model with minor modifications.

\section{AUTHOR CONTRIBUTIONS}

SN as well as FA organized investigation study then conscripted this document. HN along with FA oversaw the plan. SN along with MM completed computational studies. FA reread this document then completed ELISA. RA examined the statistics then thoroughly revised the document. All information was produced in-house in addition no paper mill was cast-off. The immunoblot method remained unused by this document, besides all information is encompassed in novel document. Here stand certainly not any information providing by way of associated records.

\section{CONFLICT OF INTEREST}

The authors declared no competing financial interest.

\section{ACKNOWLEDGMENTS}

Authors remain thankful to Riphah Institute of Pharmaceutical Sciences for contributions of chemical purchase. This work was supported by Riphah Institute of Pharmaceutical Sciences, Riphah International University, Lahore, Pakistan. 


\section{REFERENCES}

1. Adedoyin, A., Solomon, O., Oluwatosin, A. (2019). Root bark extract of Calliandra portoricensis (Jacq.) Benth. chemoprevents Nmethyl-N-nitrosourea-induced mammary gland toxicity in rats. J. Ethno. pharm. col. 233: 22-33.

2. Adefisan, A., Owumi, S., and Adaramoye, O. (2019). Root Bark Extract of Calliandra Portoricensis (Jacq.) Benth. Chemoprevents N-Methyl-NNitrosoureaInduced Mammary Gland Toxicity in Rats. J. Ethnopharmacology 233, 22-33. doi:10.1016/j.jep.2018.12.027

3. Berman, H. M., Westbrook, J., Feng, Z., Gilliland, G., Bhat, T. N., Weissing, H., Shindyalov, I. N., Bourne, P. E. (2006). The protein data bank, international tables for crystallography, Crystallography of biological macromolecules. Spr. Neth., 1(2): 675-684.

4. Ebrahimipoura, S. Y., Sheikhshoaiea, I., Castrob, J., Dusekc, M., Tohidiana, Z., Eignerc, V., Khaleghi, M. (2015). Synthesis, spectral characterization, structure studies, molecular docking and antimicrobial evaluation of new dioxidouranium(VI) complexes incorporating tetradentate N2O2 Schiff base ligands. RSC Adv. 9: 13-57.

5. Ellman, G.L., 1951. Tissue sulfhydryl groups. Arch. Biochem. Biophys. 82: 70-77.

6. Gullino PM, Pettigrew HM, Grantham FH: N-nitrosomethylurea as mammary gland carcinogen in rats. J Nat Cancer Inst 1975, 54:401-414.

7. Harbeck, N., Penault-Llorca, F., Cortes, J., Gnant, M., Houssami, N., Poortmans, P., et al. (2019). Breast cancer (Primer). Nat. Rev. Dis. Primers.

8. Hecht, F., Pessoa, C. F., Gentile, L. B., Rosenthal, D., Carvalho, D. P., and Fortunato, R. S. (2016). The Role of Oxidative Stress on Breast Cancer Development and Therapy. Tumor Biol. 37 (4), 4281-4291. doi:10.1007/ s13277-016-4873-9 
9. Hira, S., Saleem, U., Anwar, F., Sohail, M. F., Raza, Z., and Ahmad, B. (2019). ß- Carotene: A Natural Compound Improves Cognitive Impairment and Oxidative Stress in a Mouse Model of Streptozotocin-Induced Alzheimer's Disease. Biomolecules 9 (9), 441. doi:10.3390/biom9090441

10. Jabeen, M., Ahmad, S., Shahid, K., Sadiq, A., Rashid, U. (2018). Ursolic Acid Hydrazide Based Organometallic Complexes: Synthesis, Characterization, Antibacterial, Antioxidant, and Docking Studies. J. Fron. Chem. 6: 55-65.

11. Kawagoe R, Kawagoe H, Sano K. Valproic acid induces apoptosis in human leukemia cells by stimulating both caspase-dependent and -independent apoptotic signaling pathways. Leukemia research 2002;26(5):495-502.

12. Kim, K. J., Jeun, S. H., Sung, K. W. (2017). Lamotrigine, an antiepileptic drug, inhibits 5-HT3 receptor currents in NCB-20 neuroblastoma cells. Kor. J. Physio. Pharmcol. 21: 169-177.

13. Mahmoud, W. H., Deghadi, R. G., Mohamed, G. G. (2020). Metal complexes of ferrocenyl-substituted Schiff base: Preparation, characterization, molecular structure, molecular docking studies and biological investigation, J. Organometal. Chem. 2: 1-42.

14. Morris, G. M., Huey, R., Lindstrom, W., Sanner, M. F., Belew, R. K., Goodsell, D. S., Olson, J. (2009). AutoDock4 and AutoDockTools4: Automated docking with selective receptor flexibility. J. Comp. Chem. 30: 2785-2791. doi:10.1002/jcc.21256.

15. Nagini, S. (2017). Breast Cancer: Current Molecular Therapeutic Targets and $\begin{array}{llll}\text { New } & \text { Players. } & \text { Acamc } & 17\end{array}$ doi:10.2174/1871520616666160502122724 Nandi, A., Yan, L.-J., Jana, C. K., and Das, N. (2019). Role of Catalase in Oxidative Stress- and Age- Associated Degenerative Diseases. Oxidative Med. Cell Longevity 2019, 1-19. doi:10.1155/2019/9613090 
16. Najib, F. M., Mustafa, M. S. (2014). Spectrophotometric methods for simultaneous determination of carbamazepine and lamotrigine in binary mixtures and urine samples. Mal. J. Anal. Sci. 18: 491-506.

17. Nelson M, Yang M, Dowle AA, Thomas JR, Brackenbury WJ. The sodium channel- blocking antiepileptic drug phenytoin inhibits breast tumour growth and metastasis. Molecular cancer 2015;14:13 doi 10.1186/s12943-014-0277-x.

18. Olsen CM, Meussen-Elholm ET, Roste LS, Tauboll E. Antiepileptic drugs inhibit cell growth in the human breast cancer cell line MCF7. Molecular and cellular endocrinology 2004;213(2):173-9 doi 10.1016/j.mce.2003.10.032.

19. Pellegrino, M., Rizza, P., Nigro, A., Ceraldi, R., Ricci, E., Perrotta, I., Aquila, S., Lanzino, M., Ando, S., Morelli, C., Sisci, D. (2018). FoxO3 mediates the inhibitory effects of the antiepileptic drug lamotrigine on breast cancer growth. J. Ame. Ass. Can. Res. 9: 1-26.

20. Poureshghi, F., Ghandforoushan, P., Safarnejad, A., Soltani, S. (2017). Interaction of an antiepileptic drug, lamotrigine with human serum albumin (HSA): application of spectroscopic techniques and molecular modeling methods. J. Photochem. Photobio. 166: 187-192.

21. Robert, M. A. R. (2010). Cellular effect of antiepileptic drugs. Bepress., 1(1): 1-40.

22. Saima, N., Humaira, N., Kishwar, S., Fareeha A., Muhammad, M. K., Humaira, N., Muhammad, S. (2021). Schiff-Based Metal Complexes of Lamotrigine: Design, Synthesis, Characterization, and Biological Evaluation. ACS Omega. 6: 7719-7730. doi=10.1021/acsomega. $1 \mathrm{c} 00027 \&$ ref $=$ pdf

23. Siegel, R. L., Miller, K. D., and Jemal, A. (2019). Cancer Statistics, 2019. CA A. Cancer J. Clin. 69 (1), 7-34. doi:10.3322/caac.21551

24. Tessa J Murray1, Angelo A Ucci2, Maricel V Maffini1, Carlos Sonnenschein1 and Ana M Soto.2009. Histological analysis of low dose NMU effects in the rat mammary gland. BMC cancer, 9:267 doi:10.1186/1471-2407-9-267 
25. Vallés, A. S., Garbus, I., Barrantes, F. J. (2007). Lamotrigine is an open-channel blocker of the nicotinic acetylcholine receptor. Neuroreport. 18:45-50.

26. Venugopal, K., Ahmad, H., Manikandan, E., Thanagai, A. K., Kavitha, K., Moodley, M. K., Rajagopal, K., Balabhaskar, R., Bhaskar, M. (2017). The effect of anticancer activity upon Beta Vulgaris extract mediated biosynthesized silver nanoparticles against human breast (MCF-7), lungs (A549) and pharynx (Hep-2) cancer cell lines. J. Photochem. Photobio. Bot. 173: 99-107.

27. Wang, S., Liu, H., Wang, X., Lei, K., Li, G., Li, J., Liu, R., Quan, Z. (2020). Synthesis of 1,3,4-oxadiazole derivatives with anticonvulsant activity and their binding to the GABA receptor. Eur. J. Med. Chem., https://doi.org/10.1016/j.ejmech.2020.112672.

28. Wu, B., Ootani, A., Iwakiri, R., Sakata, Y., Fujise, T., Amemori, S., Yokoyama, F., Tsunada, S., Toda, S., Fujimoto, K., 2005. T cell deficiency leads to liver carcinogenesis in Azoxymethane-treated rats. Exp. Biol. Med. 231: 91-98.

29. Yang, J., Roy, A., Zhang, Y. (2013). Protein-ligand binding site recognition using complementary binding specific substructure comparison and sequence profile alignment. J. Bioinfo. 29: 2588-2595.

30. Yankuzo, H. M., Baraya, Y. u. S. a., Mustapha, Z., Wong, K. K., and Yaacob, N. S. (2018).

Immunomodulatory Effects of a Bioactive Fraction of Strobilanthes Crispus in NMU- Induced Rat Mammary Tumor Model. J. Ethnopharmacology 213, 31-37. doi:10.1016/j.jep.2017.10.024 
